\title{
RESIDUAL STRESSES IN IRON CASTINGS
}

\author{
Budic, I.; VITEZ, I. \& MARUSIC, V.
}

Abstract: During process of formation of castings residual stresses occur. The appearance of residual stresses in iron castings depend on the influence of technological parameters. Paper gives some mathematical models for calculated residual stress. Tests have been carried out on standard grating test piece made of grey cast iron, poured in sand molds. The obtained measurements have been given in tables and the residual stress has been evaluated. Mathematical model has been calculated with regression analysis.

Key words: residual stresses, influence of parameters, iron castings
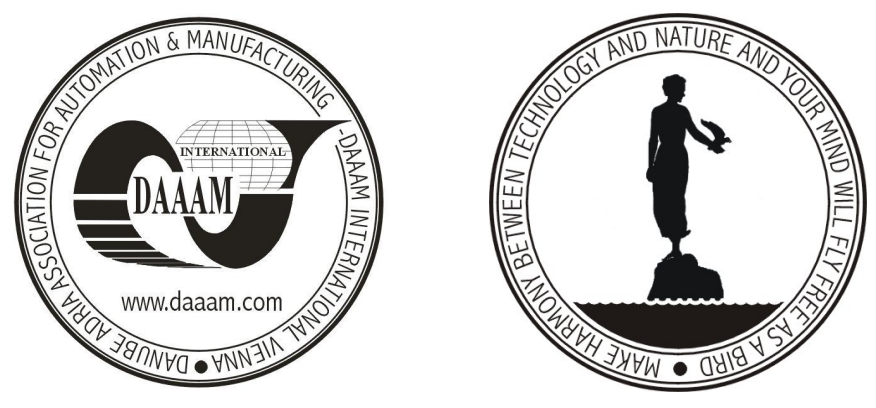

Authors' data: PhD. Prof. Budic, I[van]; PhD. Prof. Vitez, I[van]; PhD. Ass. Prof. Marusic, V[latko], Mechanical Engineering Faculty in Slavonski Brod/ University of Osijek, Croatia, ivan.budic@sfsb.hr, ivan.vitez@sfsb.hr, vlatko.marusic@sfsb.hr

This Publication has to be referred as: Budic, I.; Vitez, I. \& Marusic, V. (2007). Residual stresses in iron castings, Chapter 49 in DAAAM International Scientific Book 2007, B. Katalinic (Ed.), Published by DAAAM International, ISBN 3-90150960-7, ISSN 1726-9687, Vienna, Austria

DOI: $10.2507 /$ daaam.scibook.2007.49 